\title{
Circadian rhythms, Neuroinflammation and Oxidative Stress in the Story of Parkinson's Disease
}

\author{
Alexandre Vallée ${ }^{1, *} \mathbb{C}$, Yves Lecarpentier ${ }^{2}$, Rémy Guillevin ${ }^{1}$ and Jean-Noël Vallée ${ }^{3,4}$ \\ 1 DACTIM-MIS, Laboratory of Mathematics and Applications (LMA), UMR CNRS 7348, University of Poitiers, \\ CHU de Poitiers, 86021 Poitiers, France; remy.guillevin@chu-poitiers.fr \\ 2 Centre de Recherche Clinique, Grand Hôpital de l'Est Francilien (GHEF), 77100 Meaux, France; \\ yves.c.lecarpentier@gmail.com \\ 3 CHU Amiens Picardie, University of Picardie Jules Verne (UPJV), 80000 Amiens, France; valleejn@gmail.com \\ 4 Laboratory of Mathematics and Applications (LMA), UMR CNRS 7348, University of Poitiers, \\ 86021 Poitiers, France \\ * Correspondence: alexandre.g.vallee@gmail.com; Tel.: +33-629303240
}

Received: 10 December 2019; Accepted: 21 January 2020; Published: 28 January 2020

\begin{abstract}
Parkinson's disease (PD) is one of the main neurodegenerative disease characterized by a progressive degeneration of neurons constituted by dopamine in the substantia nigra pars compacta. The etiologies of PD remain unclear. Aging is the main risk factor for PD. Aging could dysregulate molecular pathways controlling cell homeostatic mechanisms. PD cells are the sites of several metabolic abnormalities including neuroinflammation and oxidative stress. Metabolic structures are driven by circadian rhythms. Biologic rhythms are complex systems interacting with the environment and controlling several physiological pathways. Recent findings have shown that the dysregulation of the circadian rhythms is correlated with PD and its metabolic dysregulations. This review is focused on the key role of circadian rhythms and their impact on neuroinflammation and oxidative stress in Parkinson's disease.
\end{abstract}

Keywords: circadian rhythms; Parkinson's disease; oxidative stress; neuroinflammation

\section{Introduction}

Parkinson's disease (PD) is one of the main neurodegenerative diseases (ND) characterized by a progressive degeneration of neurons constituted by dopamine in the substantia nigra pars compacta. PD is triggered in the brainstem or in the spinal cord of patients who stay asymptomatic for a long time [1,2]. The etiologies of PD remain unclear but the presence of Lewy bodies (clumps of alpha-synuclein and ubiquitin proteins in neurons which are detectable in post-mortem brain histology) has been shown. PD is marked by tremor symptom, rigidity, bradykinesia, and postural instability. These symptoms occur only when the main part of dopaminergic (DAergic) cells is lost in the substantia nigra pars compacta, which means that the smooth, coordinated regulation of striatal motor circuits is also lost [3]. Depression or rapid eye movement (REM)-associated sleep behavior disorder (RBD) are non-motor symptoms that could precede the onset of pathology.

Aging is the main risk factor for NDs. Aging could dysregulate molecular pathways controlling cell homeostatic mechanisms. Neurodegenerative cells are the sites of several metabolic abnormalities [4]. Numerous metabolic mechanisms can induce and initiate neurodegenerative mechanisms. PD shows a metabolic remodeling entailing increased oxidative stress and neuroinflammation [5,6]. Metabolic structures are driven by circadian rhythms (CRs) [7-10]. CRs are directly implicated in the regulation of the metabolic pathways observed in neurodegenerative disease and especially in PD [11,12]. Metabolic dysregulation observed in PD is the consequence of an energy metabolism reprogramming induced 
by CRs. We focused this review on the key role of CRs and their impact on neuroinflammation and oxidative stress in Parkinson's disease.

\section{Circadian rhythms (CRs)}

CRs are major biological phenomena found in all universal processes. Their endogenous characteristic is an innate oscillation associated with a period about over one day. All the studied organisms show this oscillatory process. Numerous cell functions present temporal variations driven by these oscillatory and circadian rhythms, including gene expression, metabolic reprogramming, and molecular and cellular pathways. Different integration levels allow the study of CRs as endocrinal, physiological, and neuronal cell behaviors. Although the coordination of CRs is organized by specific pacemaker structures, primary circadian oscillations are controlled at the cell level. Oscillations are determined by numerous clock genes [13]. The control of the circadian clock is based on an intracellular temporal tracking system allowing organisms to change direction and thus adapt their behavior and physiology of their life span [14]. In animals, it is well known that a specific set of transcription factors constitutes the molecular architecture of the circadian clock. These determinants are used in both positive and negative feedback which are modulated in a cell-autonomous manner [15].

Endogenous oscillations generate a freewheeling period which is close to $24 \mathrm{~h}$ to maintain for the organism constant ambient conditions. Circadian oscillations are the product of the post-transcriptional modifications of proteins [16]. A cell-autonomous transcriptional auto-regulatory complex feedback loop operates with clock gene transcriptional activators and in turn clock genes with a negative feedback role inhibit their expression by disrupting the activity of their activators. Clock and Bmal1 core clock genes encode activators and Period (Per) and Cryptochrome (Cry) encode repressors [17]. The input pathways of the retinohypothalamic tract senses external timing signals of environmental information (dark/light for example) which interact with the different compounds of the oscillators (i.e., the circadian clock genes). The oscillators are synchronized with the $24 \mathrm{~h}$ solar day. This time of day generated by the input pathways is transposed by the oscillators to output pathways to control and then to regulate the expression of circadian clock genes and thus the rhythmicity. Moreover, output pathways are predicted to be rhythmic and controlled by transcription factors or signaling. The factors activated by the circadian clock, in turn, regulate downstream the circadian clock genes in a time-of-day-specific manner [18]. This system can synchronize with its environmental time by its internal clock. To respect the environment, the input pathways are vital to maintain this timing for oscillators. At the process level, named entrainment, the input pathways can reset the activity of the oscillators to stay in the $24 \mathrm{~h}$ period of the environment [18]. Environmental cues can be detected by input pathways which in turn can modulate many mechanisms to control the activity or level of compounds of oscillators to keep a correct time of day expression. This phenomenon is observed in several environmental cues, including nutrition, social interactions, and temperature $[19,20]$. Furthermore, the clock allows a strategy named "gating" to restrict responses to environmental cues at some times of day. Diurnal mammals are insensitive to a light pulse during the day. However, during the night, a light pulse can advance or delay the clock to synchronize diurnal mammals with the environment [15]. Environmental signals can interact with molecular oscillators in some cells in complex multicellular organisms. In unicellular organisms, the cell is modulated by oscillators in response to light [21]. However, in multicellular organisms, not all cell types have sensory capabilities (as photoreception) leading to clock oscillation. The oscillators, and thus the overall rhythmicity of organisms are concentrated into compounds including a master pacemaker and peripheral oscillators [22]. Faced with these sensory inputs, rather than individual cells, the organism presents some nervous systems which possess environmental cue abilities as central oscillators or pacemakers. In humans, sensory clock inputs are localized in the brain, where signals from the master pacemaker lead to oscillators in some tissues of the organism.

Nonvisual retinal ganglion cells receive and perceive light and transmit this information to the master pacemaker (localized in the hypothalamus) through neural connections. The central pacemaker synchronizes oscillators to other tissues by using circadian input pathways from the nervous system to 
peripheral cell systems. Moreover, to maintain the entrainment of these peripheral oscillators by the environment, this central system ensures that cellular oscillations within tissues are properly in phase to provide resonance between individual cellular rhythms [23]. Melatonin operates as a synchronizer in humans and provides temporal feedback to oscillators within the nervous system to control the circadian phase and the stability of the rhythm [24]. In humans, as in other mammals, melatonin is considered as the main influencer of CRs through its action on receptors in the nervous system [25].

\section{Circadian Clock}

Some biological mechanisms in humans (such as metabolic pathways, lipid and glycose homeostasis, and autophagy) are controlled by the circadian "clock" (circadian locomotor output cycle kaput) (Figure 1). The circadian clock is present in the hypothalamic suprachiasmatic nucleus (SCN). CRs are endogenous and have entrainable free-running $24 \mathrm{~h}$ periods. Numerous transcription factors can act on the CRs. These factors are called circadian locomotor output cycle kaput (Clock), brain and muscle aryl-hydrocarbon receptor nuclear translocator-like 1 (Bmal1), Period 1 (Per1), Period 2 (Per2), Period 3 (Per3), and Cryptochrome (Cry 1 and Cry 2) [26,27]. These factors are controlled by positive and negative self-loop-regulation modulated by CRs $[15,28]$. Clock and Bmal1 heterodimerize leading to the transcription of Per1, Per2, Cry1 and Cry2 [29]. The Per/Cry heterodimer downregulates its stimulation through a negative feedback. This heterodimer translocates back to the nucleus to directly inhibit the Clock/Bmal1 complex and then to downregulate its transcription [29]. The Clock/Bmal1 complex stimulates the transcription of retinoic acid-related orphan nuclear receptors, $R e v-E r b$ and retinoid-related orphan receptors (RORs). Through a positive feedback loop, RORs activate the transcription of Bmal1, whereas through a negative feedback loop, Rev-Erb downregulates its transcription [29].

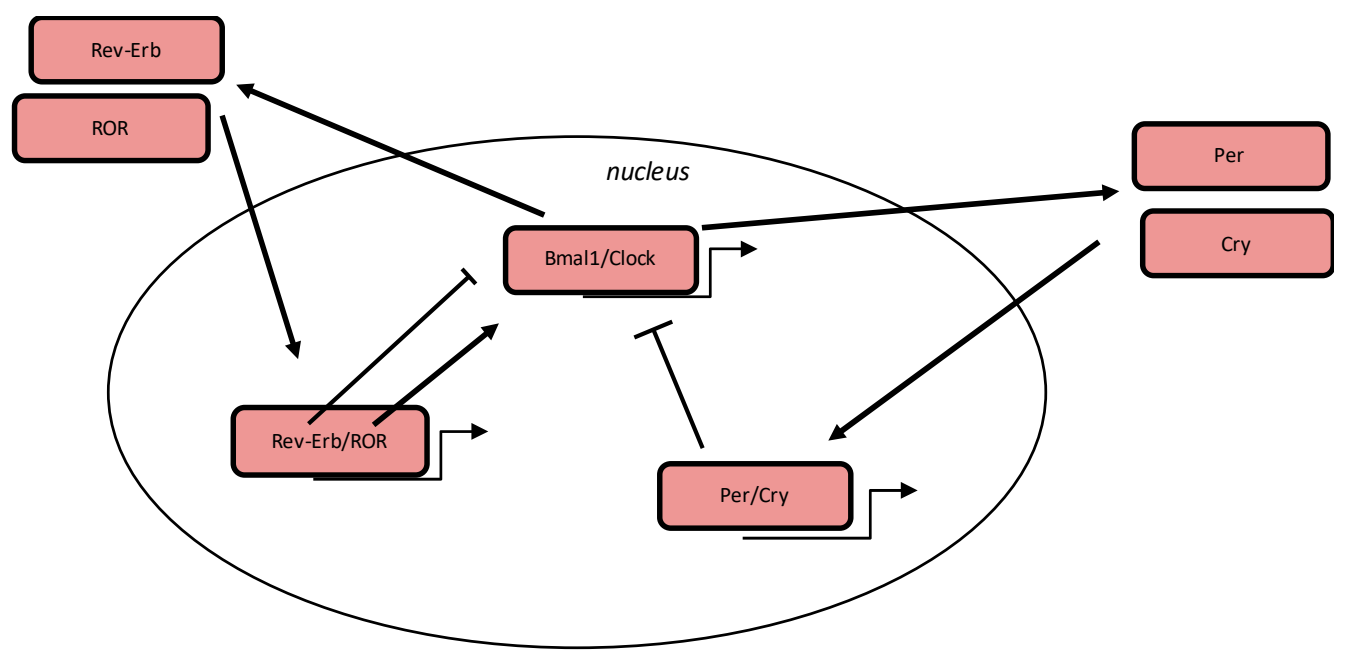

Figure 1. Circadian clock genes. The clock process is a stimulatory circle, involving the Bmal1/Clock heterodimer which activates the transcription of Period (Per) and Cryptochrome (Cry) genes, and the inhibitory feedback circle with the Per/Cry heterodimer which translocates to the nucleus and which represses the transcription of the Clock and Bmal1 genes. An additional circle implicates the retinoid-related orphan receptors (RORs) and Rev-Erb factors with a positive feedback by RORs and a negative feedback by Rev-Erb.

\section{CRs in PD}

Many studies have observed that the core clock mechanism is present in neurons and astrocytes [30,31]. Circadian dysregulation can occur in aging pathogenesis, cancers, and chronic diseases [32-34]. Aging is characterized by some modifications in the circadian system [12]. Aging is 
marked by changes in circadian rhythmicity, reducing amplitude, increasing intra-daily variability, and decreasing inter-daily stability of CRs (Figure 2) [35-37].

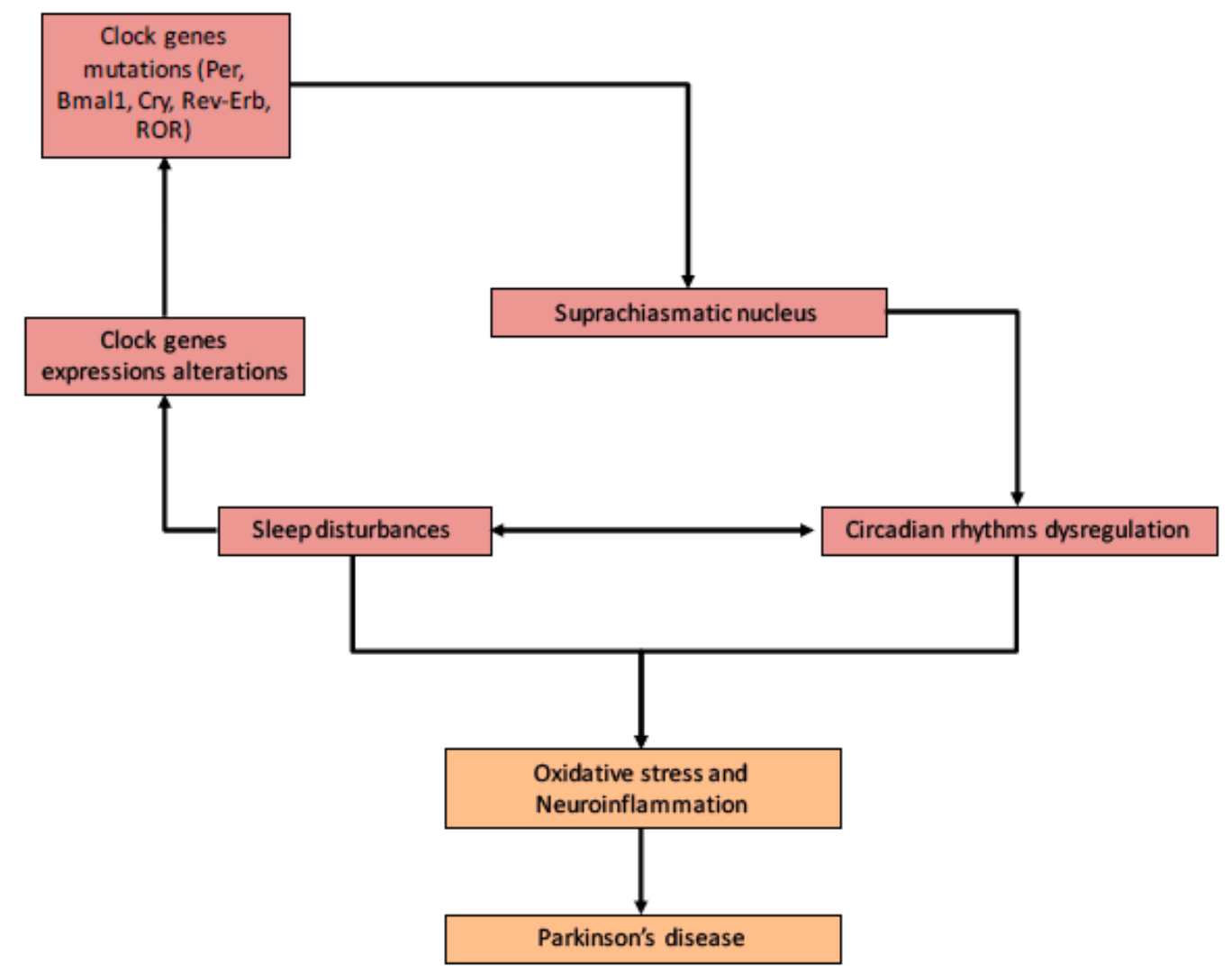

Figure 2. Circadian rhythms (CRs) and Parkinson's disease (PD). Relationship between PD, CRs, oxidative stress, and neuroinflammation. Alterations in clock genes and the melatonin pathway contribute to the dysregulation of circadian sleep rhythmicity. CRs deregulation leads to metabolism alterations (i.e., oxidative stress) and neuroinflammation contributing to PD.

Many studies have highlighted an association between CRs and PD (Table 1) [38-40]. PD patients present low levels of peak activity and amplitude of the rest-activity cycle [12]. The observed increase of physical activity and the reduction of immobility periods during the night leads to activity of the diurnal motor without oscillations [12].

In parallel, dopamine can regulate the rhythmicity of Per2 expression [41,42]. Striatal dopamine controls the Bmal1/Clock heterodimer expression [43] in a receptor-dependent manner [44]. TH (tyrosine hydroxylase), the enzyme responsible for the synthesis of dopamine, and the dopaminergic receptors show daily fluctuations [45].

CRs increase the PD neuropathology [46] although PD presents a day-to-day progression in the deterioration of the motor function [47,48]. A circadian fluctuation in PD can explain the deregulation in motor and visual performance [49]. Altered blood pressure and heart rate are common in PD. High blood pressure and heart rate have been observed under the light phase and low blood pressure has been shown during the dark phase [50]. During the day, the sympathetic activity of PD patients decreases in association with a loss of circadian rhythmicity of heart rate variability and with the lower melatonin sympathetic morning peak [51]. In PD, the elevation of cortisol and the diminution of melatonin are correlated with the alteration of the Bmal1 expression [52]. Cry1 and Per1 levels are diminished in the PD rotenone model [53], while melatonin administration can restore the level of Per1 but not Cry1 and Bmal1 levels [53]. CR systems can modulate the hypothalamic-pituitary-adrenal (HPA) axis and can restore it by promoting the dopamine function [54]. CRs are regulated by dopamine 
at the behavioral levels [55]. Decreased levels of Per2 in dorsal striatum of rats have been observed with the diminution of dopamine by 6-hydroxydopamine (6-OHDA) [41]. The activation of D2 receptors in the dopamine-depleted striatum leads to the restoration of Per2 activity [56]. During the dark span of $\mathrm{PD}$, Bmal1 expression is decreased and its expression is associated with the severity of the disease [57]. In PD, alteration of the Bmal1 levels are correlated with dopamine diminution [43,52]. Dopamine diminution can affect the central compound of the molecular clock and circadian disruption, which leads to the acceleration of PD progression [58].

Table 1. CRs, oxidative stress, inflammation and Melatonin in PD.

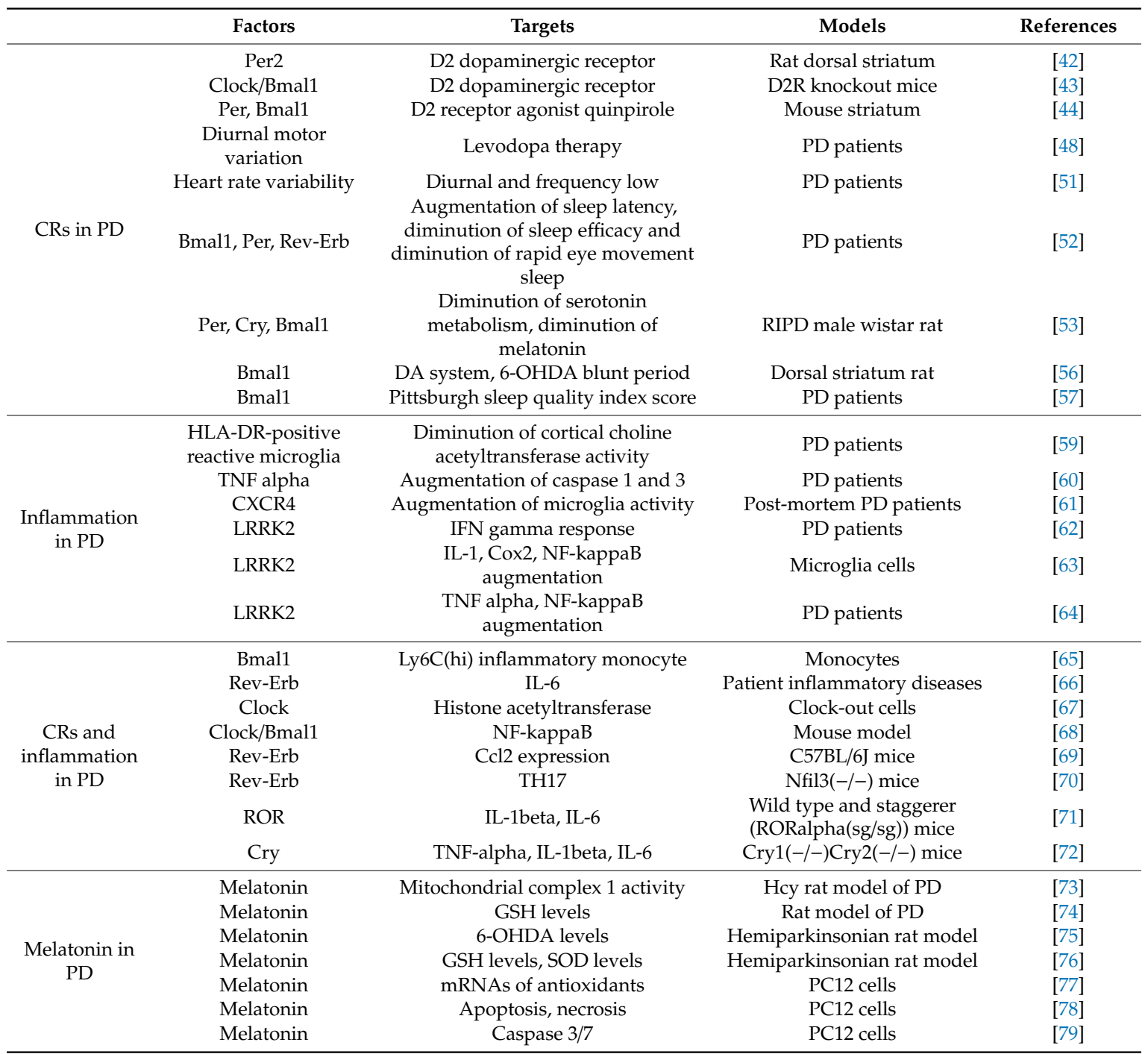

\section{Oxidative stress in PD}

Many studies have shown the increase of oxidative stress in PD [80]. Mitochondrial dysregulation have been observed in PD through the increased production and release of reactive oxygen species (ROS) [81]. Mitochondrial depletion leads to cell damage and death by the diminution of energy production through the enhancement of oxidative stress [82]. Oxidative stress and mitochondrial dysregulation lead to cell death and dementia [83-85]. The initiation of PD is correlated with oxidative stress enhancement [5]. Inhibition of the respiratory chain activity in substantia nigra pars compacta of PD is associated with the increase of ROS production and the induction of apoptosis $[81,86,87]$ (Figure 3). 


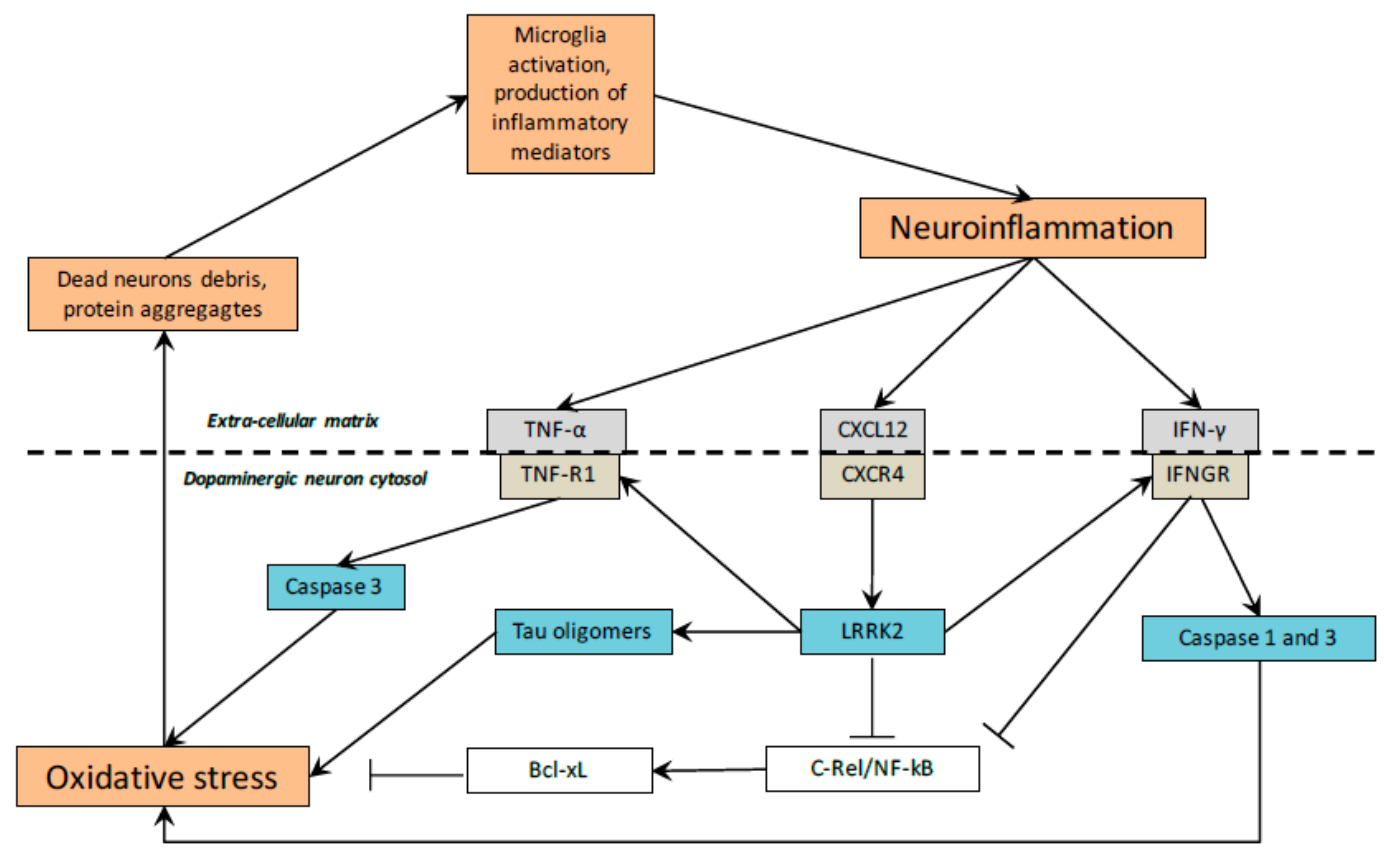

Figure 3. Neuroinflammation and oxidative stress in PD. Neuronal death induced by neuroinflammation is caused by several pathways involving oxidative stress in PD. Bcl-xL: B-cell lymphoma-extra-large; CXCL12: C-X-C motif chemokine ligand 12; IFN- $\gamma$ : interferon- $\gamma$; LRRK2: leucine-rich repeat kinase 2; NF- $\kappa$ B: nuclear factor $\kappa B$; TNF: tumor necrosis factor.

The human body generates free radicals of oxygen for oxidative metabolism. During aerobic respiration, molecular oxygen $\left(\mathrm{O}_{2}\right)$ is reduced to water molecules in each mitochondrion. By this mechanism, $\mathrm{O}_{2}, \mathrm{H}_{2} \mathrm{O}_{2}$, and $\mathrm{OH}$ are produced by a leakage of oxygen [6]. Phagocytic cells, during infections, can generate high levels of $\mathrm{NO}, \mathrm{O}_{2}$, and $\mathrm{H}_{2} \mathrm{O}_{2}$ to defend the body and thus to reduce infection. But, these produced radicals can also destroy the body cells [88].

Some enzymes, including monoamine oxidase (MAO), L-amino acid oxidase, and tyrosine hydroxylase, are involved in dopamine metabolism and in the production of ROS [89]. In parallel, inflammation is considered another source of ROS production. Nevertheless, many pathways can confluence with ROS. In microglia, the aggregation of ROS-induced proteins can induce inflammation [90]. Four mechanisms involved in PD are correlated with inflammation and ROS: the increase of iron levels, the decrease of glutathione (GSH) levels, the reduction of $26 \mathrm{~S}$ proteasomal activity, and the impairment of mitochondrial complex I regulation [91,92]. In the physiological step, MAO produces $\mathrm{H}_{2} \mathrm{O}_{2}$. In $\mathrm{PD}, \mathrm{H}_{2} \mathrm{O}_{2}$ is transformed in hydroxyl radicals $(\mathrm{OH})$ by iron via the Fenton's reactions. Thus, $\mathrm{H}_{2} \mathrm{O}_{2}$ and $\mathrm{OH}$ produce ROS [93]. GSH is oxidized by $\mathrm{H}_{2} \mathrm{O}_{2}$ and $\mathrm{OH}$ in the cytoplasm [94] leading to GSH leakage in PD. The leakage of GSH molecules leads to the conversion of glutamate and cysteine into glutamyl peptides and cysteinyl peptides. These peptides are toxic for dopaminergic cells by crossing the cellular membrane and by activating ROS into dopaminergic neurons. These peptides downregulate the activity of complex I of the mitochondria leading to ROS production and enhancement of oxidative stress [95]. Dopaminergic (DAergic) cells cannot repair misfolded proteins in PD due to the impairment of the proteasome [96]. Oxidative stress enhances the carbonylation of proteins, which is an irreversible and unrepairable modification. Carbonylation is a phenotype of cellular senescence leading to the aggregation of proteins. Protein aggregation is one of the major pathological features of nigrostriatal DAergic neurons in PD. These aggregated proteins induce neuroinflammation and oxidative stress [97]. 


\section{CRs and Oxidative Stress}

Several studies in both animals and plants have shown that the production of ROS and anti-oxidants is temporally regulated by CRs $[98,99]$. The diminution of the expression of Bmal1 is associated with the mitochondrial dysfunction leading to the increase of ROS in organs [100]. Moreover, mitochondrial dysregulation and oxidative stress have been involved in age-related diseases [101].

In Drosophila, dysregulation of Per implicates circadian oscillations in the deregulation of oxidative stress marker levels [102]. Per inhibition enhances oxidative injury and shortens lifespan [103,104]. Flies with carbonyl reductase mutation present $\mathrm{Per}$ deletion, accelerating neurodegeneration and causing neural oxidative injuries [103]. Oxidative damages in the cortex and neurodegeneration are correlated with Bmal1 depletion [105]. In the brain, Bmal1 can control the transcription of numerous redox defense genes, such as Nqo1 and Aldh2 [105]. Nqo1 encodes NADPH dehydrogenase, a critical redox defense enzyme and Aldh2 activates aldehydes during mitochondrial respiration to prevent oxidative damages and degeneration [106].

\section{Inflammation in PD}

Inflammation is one of the major cause of PD. Research studies have shown that inflammation plays a major role in PD (Table 1, Figure 3) [59]. Inflammation leads to activation of the apoptosis pathways in dopaminergic cell during PD development $[107,108]$. The correlation between inflammation and PD is mutual; inflammation leads to death of dopaminergic cells but DAergic cell death can stimulate, in a vicious feedback, inflammation [109]. Additionally, the relationship between Parkinson's disease and inflammation is mutual; while inflammation leads to dopaminergic cells death, DAergic cell death can develop or augment inflammation, that is inflammation is both cause and effect in the story of DAergic cell death [109]. Moreover, inflammatory factors induce oxidative stress, which force DAergic cells to activate death signals [110]. Some inflammatory activators have a main role in PD [111]. The stimulation of microglia leads to the activation of their pro-inflammatory enzymes (such as inducible nitric oxide synthase and cyclooxygenase) and the release of pro-inflammatory cytokines (such as C-X-C motif chemokine ligand 12 (CXCL12), tumor necrosis factor- $\alpha$ (TNF- $\alpha$ ), interferon- $\gamma$ (IFN- $\gamma$ ), interleukin (IL)-6, and IL-1 $\beta$ [112]. The NF-kB pathway has a major role in the production of these proinflammatory enzymes and cytokines in microglia [113]. TNF- $\alpha$ leads to apoptosis by TNF-R1 receptor death domain activating the caspases 1 and 3 [60]. TNF- $\alpha$ also downregulates c-Rel-NF-kB. c-Rel-NF-kB presents a neuroprotective role through the inhibition of apoptosis via B-cell lymphoma-extra-large pathway in dopaminergic neurons [113]. High-levels of CXCR4 (called fusin) expression and its ligand CXCL12 have been shown in PD. The complex formed by CXCR4-CXCL12 activates caspase 3, which leads to neural cell death via apoptosis $[61,114]$. The complex of IFN- $\gamma$-IFNGR signaling phosphorylates leucine-rich repeat kinase 2 (LRRK2) protein [62]. LRRK2 interacts with numerous cell processes in microglia and dopaminergic neurons. Activated LRRK2 protein inhibits the expression of c-Rel-NF-kB. Thus, inflammation is increased by the insufficiency of c-Rel-NF-kB [63,64]. LRRK2 activation is responsible for the formation of tau oligomers, which activate cell death signals $[115,116]$. LRRK2 controls some vesicles trafficking in cells and its overexpression is associated with the augmentation of inflammatory cytokines [117].

\section{CRs and Inflammation}

Some diurnal variations have been shown in Ly6Chi monocytes, which are the main line of defense against infection (Figure 2, Table 1) [65]. Bmal1 can act as an anti-inflammatory factor by inhibiting CCL2 expression. CCL2 is a chemokine which stimulates monocyte recruitment to the infection site by binding to the E-box present on the $\mathrm{Ccl} 2$ gene promoter region. Moreover, Bmal1 possesses two microRNA-binding sites in its 3'-UTR leading to the dysregulation of clock control and CRs control of inflammation [118]. Deficiency in Bmal1 is associated with high levels of IL-6 in response of lipopolysaccharide stimulation [66]. 
The Clock gene can acetylate the receptor of glucocorticoid receptors leading to the dysregulation of the immune system [67]. The overstimulation of Clock expression is correlated with phosphorylation and acetylation of p65 leading to the enhancement of transcriptional activity of the NF- $\mathrm{kB}$ pathway [68]. Some studies have shown that the dysregulation of the Clock activity is associated with infection [119].

$R E V$-ErB $\alpha$ can inhibit IL-6 expression [66]. In macrophage cells, Rev-Erb $\alpha$ can decrease Ccl2 expression by directly binding to the RORE motif on the promoter region of $C c l 2$ gene [69]. Moreover, Bmal1 and REV-Erb $\alpha$ can cooperate in the regulation of $C c l 2$ expression [70]. Bmal1 is responsible for the regulation of $R O R \alpha$ which can induce the transcription of $\mathrm{I} \kappa \mathrm{B} \alpha$, an inhibitor of NF- $\mathrm{kB}$ pathway [71]. Deficiency in Per2 is associated with diurnal variations in IFN-gamma expression leading to the impairment function of natural killer cells [120]. Per2 knockout reduces levels of TNF- $\alpha$ and IL-12 [121]. In macrophages, Per 2 mRNA rhythms act as inverse phase to Bmal1 [122]. Per2 is considered as a negative compound of the $\mathrm{CR}$ feedback loop and then, can promote inflammation through the inhibition of the complex Bmal1/Clock [123]. Moreover, Per2 can also decrease REV-ErB $\alpha$ function responsible for activation of inflammation response [123]. Deficiency in Cry1 and Cry2 leads to CAMP overproduction and PKA activity (protein kinase A) increasing p65 phosphorylation and NF- $\mathrm{KB}$ pathway [124]. Administration of anti-TNF- $\alpha$ is associated with both reduction of inflammation and Cry expression [72].

\section{Melatonin: A Potential Therapeutic Drug in PD}

Melatonin (also named 5-methoxy-N-acetyltryptamine) is a natural product of the pineal gland [125]. Melatonin controls the regulation of sleep (Table 1) [126,127]. Its production has been shown during darkness and thus, may participate in sleep circadian regulation $[128,129]$. Diminution of melatonin amplitude rhythms is correlated with aging [37,130], and its deregulation has been shown in numerous neurodegenerative diseases (such as Alzheimer's disease and Parkinson's disease) [131]. Melatonin presents some effects, such as anti-inflammatory, anti-oxidant, and neuroprotective effects $[128,132-136]$. Melatonin increases the potential of mitochondrial membrane, activates mitochondrial biogenesis [137], and increases the mitochondrial function [138].

\section{Melatonin and Oxidative Stress in PD}

In PD, few studies have investigated the different effects of melatonin on oxidative stress. Melatonin administration is associated with the increase of superoxide dismutase (SOD), GSH, and mitochondrial complex-I activity in the rat model of PD. In parallel, melatonin administration is correlated with the decrease of $\mathrm{OH}$ and the increase of catalase [73]. GSH expression, and GSSG/GSH ratio are increased after melatonin administration in the rat model of PD [74]. Malondialdehyde (MDA) expression, a marker of oxidative stress, is decreased while SOD is increased under melatonin administration in rat model of PD induced by 6-OHDA or by MPTP [75]. In the same way, other models of PD rats induced by rotenone have shown the increase of both GSH and SOD after melatonin administration [76]. In PD, melatonin can decrease the number of degenerating neurons and lipid peroxidation [139]. Recent studies have shown that melatonin is associated with the decrease of oxidative stress in rats of PD induced by $\mathrm{MPP}(+)$ [140] and in mice of PD induced by MPTP [141]. Few studies in humans have investigated the role of melatonin on oxidative stress in PD. In PC12 cells, melatonin administration is associated with the protection against the reduction of mRNAs of antioxidant enzymes evoked by 6-OHDA [77], with the reduction of apoptosis and necrosis [78], and with the prevention of mitochondrial dysregulation [79].

\section{Melatonin and Neuroinflammation in PD}

Few studies have focused on the effects of melatonin on inflammation in PD. Melatonin administration can prevent the increase of iNOS in PD mice-induced MPTP [142]. iNOS, increased in striatum and substantia nigra of PD, leads to stimulation of nitric oxide production and neuroinflammation in PD [143]. 
COX2 is responsible for the involvement of neuroinflammation in PD [143]. COX2 expression is decreased under melatonin administration in PD mice-induced MPTP [141].

\section{Conclusions}

Aging is involved in the pathophysiology of PD and dysregulates several molecular pathways controlling cell homeostasis. Metabolic abnormalities have been observed in PD. This review highlights the main role of both inflammation and oxidative stress in PD. These signals operate together to alter the cellular activity in PD. In parallel, CRs can control metabolic structures and thus, can regulate the metabolic pathways involved in PD. A metabolic reprogramming expressed by oxidative stress in concordance with inflammation operates in PD under the control of CRs. Looking for signs of early circadian dysregulation could help to diagnose PD before the onset of known symptoms or could allow the rapid introduction of therapeutic strategies. Melatonin, a major marker of CRs, could be an interesting target in PD therapeutic strategy. However, few studies have focused on the interactions between melatonin with oxidative stress and inflammation in PD. Future clinical trials could be implemented to study the efficacy of melatonin in PD by directly targeting these two signals.

Author Contributions: All authors listed have contributed to the work, and approved it for submitting to publication.

Funding: This research received no external funding.

Conflicts of Interest: The authors declare that the research was conducted in the absence of any commercial or financial relationship that could be construed as a potential conflict of interest.

\section{Abbreviations}

Bmal1: brain and muscle aryl-hydrocarbon receptor nuclear translocator-like 1; Clock: circadian locomotor output cycles kaput; PD: Parkinson's disease; Per: period; RORs: retinoid-related orphan receptors. Bcl-xL: B-cell lymphoma-extra-large; CXCL12: C-X-C motif chemokine ligand 12; IFN- $\gamma$ : interferon- $\gamma$; LRRK2: leucine-rich repeat kinase 2; NF- $\mathrm{kB}$ : nuclear factor $\mathrm{kB}$; TNF: tumor necrosis factor.

\section{References}

1. Braak, H.; Ghebremedhin, E.; Rüb, U.; Bratzke, H.; Del Tredici, K. Stages in the development of Parkinson's disease-related pathology. Cell Tissue Res. 2004, 318, 121-134. [CrossRef]

2. Grinberg, L.T.; Rueb, U.; di Lorenzo Alho, A.T.; Heinsen, H. Brainstem pathology and non-motor symptoms in PD. J. Neurol. Sci. 2010, 289, 81-88. [CrossRef] [PubMed]

3. Maguire-Zeiss, K.A.; Federoff, H.J. Future directions for immune modulation in neurodegenerative disorders: Focus on Parkinson's disease. J. Neural Transm. 2010, 117, 1019-1025. [CrossRef] [PubMed]

4. Yin, F.; Boveris, A.; Cadenas, E. Mitochondrial energy metabolism and redox signaling in brain aging and neurodegeneration. Antioxid. Redox Signal. 2014, 20, 353-371. [CrossRef] [PubMed]

5. Kim, G.H.; Kim, J.E.; Rhie, S.J.; Yoon, S. The Role of Oxidative Stress in Neurodegenerative Diseases. Exp. Neurobiol. 2015, 24, 325-340. [CrossRef]

6. Vallée, A.; Lecarpentier, Y.; Guillevin, R.; Vallée, J.-N. Thermodynamics in Neurodegenerative Diseases: Interplay Between Canonical WNT/Beta-Catenin Pathway-PPAR Gamma, Energy Metabolism and Circadian Rhythms. Neuromolecular Med. 2018, 20, 174-204. [CrossRef]

7. Goldbeter, A. Dissipative structures and biological rhythms. Chaos Woodbury N 2017, 27, 104612. [CrossRef]

8. Lecarpentier, Y.; Claes, V.; Krokidis, X.; Hébert, J.-L.; Timbely, O.; Blanc, J.-F.; Michel, F.; Vallée, A. Comparative Statistical Mechanics of Muscle and Non-Muscle Contractile Systems: Stationary States of Near-Equilibrium Systems in A Linear Regime. Entropy 2017, 19, 558. [CrossRef]

9. Prigogine, I. Life and physics. New perspectives. Cell Biophys. 1986, 9, 217-224. [CrossRef]

10. Prigogine, I.; Nicolis, G.; Babloyantz, A. Nonequilibrium problems in biological phenomena. Ann. N. Y. Acad. Sci. 1974, 231, 99-105. [CrossRef]

11. Vallée, A.; Lecarpentier, Y.; Vallée, J.-N. Circadian Rhythms and Energy Metabolism Reprogramming in Parkinson's Disease. Curr. Issues Mol. Biol. 2019, 31, 21-44. [CrossRef] [PubMed] 
12. Videnovic, A.; Zee, P.C. Consequences of Circadian Disruption on Neurologic Health. Sleep Med. Clin. 2015, 10, 469-480. [CrossRef] [PubMed]

13. Mackey, S.R.; Golden, S.S.; Ditty, J.L. The itty-bitty time machine genetics of the cyanobacterial circadian clock. Adv. Genet. 2011, 74, 13-53. [PubMed]

14. Dunlap, J.C. Molecular bases for circadian clocks. Cell 1999, 96, 271-290. [CrossRef]

15. Reppert, S.M.; Weaver, D.R. Coordination of circadian timing in mammals. Nature 2002, 418, $935-941$. [CrossRef] [PubMed]

16. Hastings, M.H.; Maywood, E.S.; Brancaccio, M. The Mammalian Circadian Timing System and the Suprachiasmatic Nucleus as Its Pacemaker. Biology 2019, 8, 13. [CrossRef]

17. Atger, F.; Mauvoisin, D.; Weger, B.; Gobet, C.; Gachon, F. Regulation of Mammalian Physiology by Interconnected Circadian and Feeding Rhythms. Front. Endocrinol. 2017, 8, 42. [CrossRef]

18. Johnson, C.H.; Elliott, J.A.; Foster, R. Entrainment of circadian programs. Chronobiol. Int. 2003, 20, 741-774. [CrossRef]

19. Carneiro, B.T.S.; Araujo, J.F. Food entrainment: Major and recent findings. Front. Behav. Neurosci. 2012, 6, 83. [CrossRef]

20. Bloch, G.; Herzog, E.D.; Levine, J.D.; Schwartz, W.J. Socially synchronized circadian oscillators. Proc. Biol. Sci. 2013, 280, 20130035. [CrossRef]

21. Bell-Pedersen, D.; Cassone, V.M.; Earnest, D.J.; Golden, S.S.; Hardin, P.E.; Thomas, T.L.; Zoran, M.J. Circadian rhythms from multiple oscillators: Lessons from diverse organisms. Nat. Rev. Genet. 2005, 6, 544-556. [CrossRef] [PubMed]

22. Mohawk, J.A.; Green, C.B.; Takahashi, J.S. Central and peripheral circadian clocks in mammals. Annu. Rev. Neurosci. 2012, 35, 445-462. [CrossRef] [PubMed]

23. Dibner, C.; Schibler, U.; Albrecht, U. The mammalian circadian timing system: Organization and coordination of central and peripheral clocks. Annu. Rev. Physiol. 2010, 72, 517-549. [CrossRef] [PubMed]

24. Cassone, V.M. Effects of melatonin on vertebrate circadian systems. Trends Neurosci. 1990, 13, 457-464. [CrossRef]

25. Weaver, D.R.; Stehle, J.H.; Stopa, E.G.; Reppert, S.M. Melatonin receptors in human hypothalamus and pituitary: Implications for circadian and reproductive responses to melatonin. J. Clin. Endocrinol. Metab. 1993, 76, 295-301. [PubMed]

26. Hogenesch, J.B.; Gu, Y.Z.; Jain, S.; Bradfield, C.A. The basic-helix-loop-helix-PAS orphan MOP3 forms transcriptionally active complexes with circadian and hypoxia factors. Proc. Natl. Acad. Sci. USA 1998, 95, 5474-5479. [CrossRef]

27. Gekakis, N.; Staknis, D.; Nguyen, H.B.; Davis, F.C.; Wilsbacher, L.D.; King, D.P.; Takahashi, J.S.; Weitz, C.J. Role of the CLOCK protein in the mammalian circadian mechanism. Science 1998, 280, 1564-1569. [CrossRef]

28. Schibler, U.; Sassone-Corsi, P. A web of circadian pacemakers. Cell 2002, 111, 919-922. [CrossRef]

29. Ko, C.H.; Takahashi, J.S. Molecular components of the mammalian circadian clock. Hum. Mol. Genet. 2006, 15, R271-R277. [CrossRef]

30. Abe, M.; Herzog, E.D.; Yamazaki, S.; Straume, M.; Tei, H.; Sakaki, Y.; Menaker, M.; Block, G.D. Circadian rhythms in isolated brain regions. J. Neurosci. Off. J. Soc. Neurosci. 2002, 22, 350-356. [CrossRef]

31. Marpegan, L.; Swanstrom, A.E.; Chung, K.; Simon, T.; Haydon, P.G.; Khan, S.K.; Liu, A.C.; Herzog, E.D.; Beaulé, C. Circadian regulation of ATP release in astrocytes. J. Neurosci. Off. J. Soc. Neurosci. 2011, 31, 8342-8350. [CrossRef]

32. Anea, C.B.; Zhang, M.; Stepp, D.W.; Simkins, G.B.; Reed, G.; Fulton, D.J.; Rudic, R.D. Vascular disease in mice with a dysfunctional circadian clock. Circulation 2009, 119, 1510-1517. [CrossRef]

33. Bass, J.; Takahashi, J.S. Circadian integration of metabolism and energetics. Science 2010, 330, 1349-1354. [CrossRef]

34. Evans, J.A.; Davidson, A.J. Health consequences of circadian disruption in humans and animal models. Prog. Mol. Biol. Transl. Sci. 2013, 119, 283-323. [PubMed]

35. Czeisler, C.A.; Dumont, M.; Duffy, J.F.; Steinberg, J.D.; Richardson, G.S.; Brown, E.N.; Sánchez, R.; Ríos, C.D.; Ronda, J.M. Association of sleep-wake habits in older people with changes in output of circadian pacemaker. Lancet Lond. Engl. 1992, 340, 933-936. [CrossRef]

36. Hofman, M.A. The human circadian clock and aging. Chronobiol. Int. 2000, 17, 245-259. [CrossRef] [PubMed] 
37. Duffy, J.F.; Zeitzer, J.M.; Rimmer, D.W.; Klerman, E.B.; Dijk, D.-J.; Czeisler, C.A. Peak of circadian melatonin rhythm occurs later within the sleep of older subjects. Am. J. Physiol. Endocrinol. Metab. 2002, 282, E297-E303. [CrossRef]

38. Abbott, R.D.; Ross, G.W.; White, L.R.; Tanner, C.M.; Masaki, K.H.; Nelson, J.S.; Curb, J.D.; Petrovitch, H. Excessive daytime sleepiness and subsequent development of Parkinson disease. Neurology 2005, 65, 1442-1446. [CrossRef]

39. Weishaupt, J.H.; Bartels, C.; Pölking, E.; Dietrich, J.; Rohde, G.; Poeggeler, B.; Mertens, N.; Sperling, S.; Bohn, M.; Hüther, G.; et al. Reduced oxidative damage in ALS by high-dose enteral melatonin treatment. J. Pineal Res. 2006, 41, 313-323. [CrossRef]

40. Gao, J.; Huang, X.; Park, Y.; Hollenbeck, A.; Blair, A.; Schatzkin, A.; Chen, H. Daytime napping, nighttime sleeping, and Parkinson disease. Am. J. Epidemiol. 2011, 173, 1032-1038. [CrossRef]

41. Hood, S.; Cassidy, P.; Cossette, M.-P.; Weigl, Y.; Verwey, M.; Robinson, B.; Stewart, J.; Amir, S. Endogenous dopamine regulates the rhythm of expression of the clock protein PER2 in the rat dorsal striatum via daily activation of D2 dopamine receptors. J. Neurosci. Off. J. Soc. Neurosci. 2010, 30, 14046-14058. [CrossRef] [PubMed]

42. Videnovic, A.; Golombek, D. Circadian and sleep disorders in Parkinson's disease. Exp. Neurol. 2013, 243, 45-56. [CrossRef] [PubMed]

43. Yujnovsky, I.; Hirayama, J.; Doi, M.; Borrelli, E.; Sassone-Corsi, P. Signaling mediated by the dopamine D2 receptor potentiates circadian regulation by CLOCK:BMAL1. Proc. Natl. Acad. Sci. USA 2006, 103, 6386-6391. [CrossRef] [PubMed]

44. Imbesi, M.; Yildiz, S.; Dirim Arslan, A.; Sharma, R.; Manev, H.; Uz, T. Dopamine receptor-mediated regulation of neuronal "clock" gene expression. Neuroscience 2009, 158, 537-544. [CrossRef]

45. Parekh, P.K.; Ozburn, A.R.; McClung, C.A. Circadian clock genes: Effects on dopamine, reward and addiction. Alcohol Fayettev. N 2015, 49, 341-349. [CrossRef]

46. Lauretti, E.; Di Meco, A.; Merali, S.; Praticò, D. Circadian rhythm dysfunction: A novel environmental risk factor for Parkinson's disease. Mol. Psychiatry 2017, 22, 280-286. [CrossRef]

47. Piccini, P.; Del Dotto, P.; Pardini, C.; D’Antonio, P.; Rossi, G.; Bonuccelli, U. Diurnal worsening in Parkinson patients treated with levodopa. Riv. Neurol. 1991, 61, 219-224.

48. Bonuccelli, U.; Del Dotto, P.; Lucetti, C.; Petrozzi, L.; Bernardini, S.; Gambaccini, G.; Rossi, G.; Piccini, P. Diurnal motor variations to repeated doses of levodopa in Parkinson's disease. Clin. Neuropharmacol. 2000, 23, 28-33. [CrossRef]

49. Struck, L.K.; Rodnitzky, R.L.; Dobson, J.K. Circadian fluctuations of contrast sensitivity in Parkinson's disease. Neurology 1990, 40, 467-470. [CrossRef]

50. Chen, L.; Yang, G. PPARs Integrate the Mammalian Clock and Energy Metabolism. PPAR Res. 2014, 2014, 653017. [CrossRef]

51. Devos, D.; Kroumova, M.; Bordet, R.; Vodougnon, H.; Guieu, J.D.; Libersa, C.; Destee, A. Heart rate variability and Parkinson's disease severity. J. Neural Transm. 2003, 110, 997-1011.

52. Breen, D.P.; Vuono, R.; Nawarathna, U.; Fisher, K.; Shneerson, J.M.; Reddy, A.B.; Barker, R.A. Sleep and circadian rhythm regulation in early Parkinson disease. JAMA Neurol. 2014, 71, 589-595. [CrossRef] [PubMed]

53. Mattam, U.; Jagota, A. Daily rhythms of serotonin metabolism and the expression of clock genes in suprachiasmatic nucleus of rotenone-induced Parkinson's disease male Wistar rat model and effect of melatonin administration. Biogerontology 2015, 16, 109-123. [CrossRef] [PubMed]

54. Mizobuchi, M.; Hineno, T.; Kakimoto, Y.; Hiratani, K. Increase of plasma adrenocorticotrophin and cortisol in 1-methyl-4-phenyl-1,2,3,6-tetrahydropyridine (MPTP)-treated dogs. Brain Res. 1993, 612, 319-321. [CrossRef]

55. Videnovic, A.; Willis, G.L. Circadian system - A novel diagnostic and therapeutic target in Parkinson's disease? Mov. Disord. Off. J. Mov. Disord. Soc. 2016, 31, 260-269. [CrossRef] [PubMed]

56. Gravotta, L.; Gavrila, A.M.; Hood, S.; Amir, S. Global depletion of dopamine using intracerebroventricular 6-hydroxydopamine injection disrupts normal circadian wheel-running patterns and PERIOD2 expression in the rat forebrain. J. Mol. Neurosci. MN 2011, 45, 162-171. [CrossRef]

57. Cai, Y.; Liu, S.; Sothern, R.B.; Xu, S.; Chan, P. Expression of clock genes Per1 and Bmal1 in total leukocytes in health and Parkinson's disease. Eur. J. Neurol. 2010, 17, 550-554. [CrossRef]

58. Kondratova, A.A.; Kondratov, R.V. The circadian clock and pathology of the ageing brain. Nat. Rev. Neurosci. 2012, 13, 325-335. [CrossRef] 
59. McGeer, P.L.; Itagaki, S.; Boyes, B.E.; McGeer, E.G. Reactive microglia are positive for HLA-DR in the substantia nigra of Parkinson's and Alzheimer's disease brains. Neurology 1988, 38, 1285-1291. [CrossRef]

60. Mogi, M.; Togari, A.; Kondo, T.; Mizuno, Y.; Komure, O.; Kuno, S.; Ichinose, H.; Nagatsu, T. Caspase activities and tumor necrosis factor receptor R1 (p55) level are elevated in the substantia nigra from parkinsonian brain. J. Neural Transm. 2000, 107, 335-341. [CrossRef]

61. Shimoji, M.; Pagan, F.; Healton, E.B.; Mocchetti, I. CXCR4 and CXCL12 expression is increased in the nigro-striatal system of Parkinson's disease. Neurotox. Res. 2009, 16, 318-328. [CrossRef] [PubMed]

62. Gardet, A.; Benita, Y.; Li, C.; Sands, B.E.; Ballester, I.; Stevens, C.; Korzenik, J.R.; Rioux, J.D.; Daly, M.J.; Xavier, R.J.; et al. LRRK2 is involved in the IFN-gamma response and host response to pathogens. J. Immunol. Baltim. Md 1950 2010, 185, 5577-5585.

63. Russo, I.; Berti, G.; Plotegher, N.; Bernardo, G.; Filograna, R.; Bubacco, L.; Greggio, E. Leucine-rich repeat kinase 2 positively regulates inflammation and down-regulates NF- $\mathrm{B}$ p50 signaling in cultured microglia cells. J. Neuroinflammation 2015, 12, 230. [CrossRef]

64. López de Maturana, R.; Lang, V.; Zubiarrain, A.; Sousa, A.; Vázquez, N.; Gorostidi, A.; Águila, J.; López de Munain, A.; Rodríguez, M.; Sánchez-Pernaute, R. Mutations in LRRK2 impair NF-kB pathway in iPSC-derived neurons. J. Neuroinflammation 2016, 13, 295. [CrossRef] [PubMed]

65. Nguyen, K.D.; Fentress, S.J.; Qiu, Y.; Yun, K.; Cox, J.S.; Chawla, A. Circadian gene Bmal1 regulates diurnal oscillations of Ly6C(hi) inflammatory monocytes. Science 2013, 341, 1483-1488. [CrossRef] [PubMed]

66. Gibbs, J.E.; Blaikley, J.; Beesley, S.; Matthews, L.; Simpson, K.D.; Boyce, S.H.; Farrow, S.N.; Else, K.J.; Singh, D.; Ray, D.W.; et al. The nuclear receptor REV-ERB $\alpha$ mediates circadian regulation of innate immunity through selective regulation of inflammatory cytokines. Proc. Natl. Acad. Sci. USA 2012, 109, 582-587. [CrossRef] [PubMed]

67. Doi, M.; Hirayama, J.; Sassone-Corsi, P. Circadian regulator CLOCK is a histone acetyltransferase. Cell 2006, 125, 497-508. [CrossRef] [PubMed]

68. Spengler, M.L.; Kuropatwinski, K.K.; Comas, M.; Gasparian, A.V.; Fedtsova, N.; Gleiberman, A.S.; Gitlin, I.I.; Artemicheva, N.M.; Deluca, K.A.; Gudkov, A.V.; et al. Core circadian protein CLOCK is a positive regulator of NF-kB-mediated transcription. Proc. Natl. Acad. Sci. USA 2012, 109, E2457-E2465. [CrossRef]

69. Sato, S.; Sakurai, T.; Ogasawara, J.; Takahashi, M.; Izawa, T.; Imaizumi, K.; Taniguchi, N.; Ohno, H.; Kizaki, T. A circadian clock gene, Rev-erb $\alpha$, modulates the inflammatory function of macrophages through the negative regulation of Ccl2 expression. J. Immunol. 2014, 192, 407-417. [CrossRef]

70. Yu, X.; Rollins, D.; Ruhn, K.A.; Stubblefield, J.J.; Green, C.B.; Kashiwada, M.; Rothman, P.B.; Takahashi, J.S.; Hooper, L.V. TH17 cell differentiation is regulated by the circadian clock. Science 2013, 342, 727-730. [CrossRef]

71. Stapleton, C.M.; Jaradat, M.; Dixon, D.; Kang, H.S.; Kim, S.-C.; Liao, G.; Carey, M.A.; Cristiano, J.; Moorman, M.P.; Jetten, A.M. Enhanced susceptibility of staggerer (RORalphasg/sg) mice to lipopolysaccharide-induced lung inflammation. Am. J. Physiol. Lung Cell. Mol. Physiol. 2005, 289, L144-L152. [CrossRef] [PubMed]

72. Hashiramoto, A.; Yamane, T.; Tsumiyama, K.; Yoshida, K.; Komai, K.; Yamada, H.; Yamazaki, F.; Doi, M.; Okamura, H.; Shiozawa, S. Mammalian clock gene Cryptochrome regulates arthritis via proinflammatory cytokine TNF-alpha. J. Immunol. 2010, 184, 1560-1565.

73. Paul, R.; Phukan, B.C.; Justin Thenmozhi, A.; Manivasagam, T.; Bhattacharya, P.; Borah, A. Melatonin protects against behavioral deficits, dopamine loss and oxidative stress in homocysteine model of Parkinson's disease. Life Sci. 2018, 192, 238-245. [CrossRef]

74. Chen, S.T.; Chuang, J.I.; Hong, M.H.; Li, E.I.-C. Melatonin attenuates MPP+-induced neurodegeneration and glutathione impairment in the nigrostriatal dopaminergic pathway. J. Pineal Res. 2002, 32, 262-269. [CrossRef]

75. Ozsoy, O.; Yildirim, F.B.; Ogut, E.; Kaya, Y.; Tanriover, G.; Parlak, H.; Agar, A.; Aslan, M. Melatonin is protective against 6-hydroxydopamine-induced oxidative stress in a hemiparkinsonian rat model. Free Radic. Res. 2015, 49, 1004-1014. [CrossRef]

76. Saravanan, K.S.; Sindhu, K.M.; Mohanakumar, K.P. Melatonin protects against rotenone-induced oxidative stress in a hemiparkinsonian rat model. J. Pineal Res. 2007, 42, 247-253. [CrossRef]

77. Mayo, J.C.; Sainz, R.M.; Uria, H.; Antolin, I.; Esteban, M.M.; Rodriguez, C. Melatonin prevents apoptosis induced by 6-hydroxydopamine in neuronal cells: Implications for Parkinson's disease. J. Pineal Res. 1998, 24, 179-192. [CrossRef] 
78. Mayo, J.C.; Sainz, R.M.; Antolín, I.; Rodriguez, C. Ultrastructural confirmation of neuronal protection by melatonin against the neurotoxin 6-hydroxydopamine cell damage. Brain Res. 1999, 818, 221-227. [CrossRef]

79. Ishido, M. Melatonin inhibits maneb-induced aggregation of alpha-synuclein in rat pheochromocytoma cells. J. Pineal Res. 2007, 42, 125-130. [CrossRef]

80. Giordano, S.; Darley-Usmar, V.; Zhang, J. Autophagy as an essential cellular antioxidant pathway in neurodegenerative disease. Redox Biol. 2014, 2, 82-90. [CrossRef]

81. Franco-Iborra, S.; Vila, M.; Perier, C. The Parkinson Disease Mitochondrial Hypothesis: Where Are We at? Neurosci. Rev. J. Bringing Neurobiol. Neurol. Psychiatry 2016, 22, 266-277. [CrossRef]

82. Luque-Contreras, D.; Carvajal, K.; Toral-Rios, D.; Franco-Bocanegra, D.; Campos-Peña, V. Oxidative stress and metabolic syndrome: Cause or consequence of Alzheimer's disease? Oxid. Med. Cell. Longev. 2014, 2014, 497802. [CrossRef]

83. Benilova, I.; Karran, E.; De Strooper, B. The toxic A $\beta$ oligomer and Alzheimer's disease: An emperor in need of clothes. Nat. Neurosci. 2012, 15, 349-357. [CrossRef]

84. Sochocka, M.; Koutsouraki, E.S.; Gasiorowski, K.; Leszek, J. Vascular oxidative stress and mitochondrial failure in the pathobiology of Alzheimer's disease: A new approach to therapy. CNS Neurol. Disord. Drug Targets 2013, 12, 870-881. [CrossRef]

85. Islam, M.T. Oxidative stress and mitochondrial dysfunction-linked neurodegenerative disorders. Neurol. Res. 2017, 39, 73-82. [CrossRef]

86. Schapira, A.H.V. Mitochondria in the aetiology and pathogenesis of Parkinson's disease. Lancet Neurol. 2008, 7, 97-109. [CrossRef]

87. Blesa, J.; Trigo-Damas, I.; Quiroga-Varela, A.; Jackson-Lewis, V.R. Oxidative stress and Parkinson's disease. Front. Neuroanat. 2015, 9, 91. [CrossRef]

88. Ames, B.N.; Shigenaga, M.K.; Hagen, T.M. Oxidants, antioxidants, and the degenerative diseases of aging. Proc. Natl. Acad. Sci. USA 1993, 90, 7915-7922. [CrossRef]

89. Coyle, J.T.; Puttfarcken, P. Oxidative stress, glutamate, and neurodegenerative disorders. Science 1993, 262, 689-695. [CrossRef]

90. Surace, M.J.; Block, M.L. Targeting microglia-mediated neurotoxicity: The potential of NOX2 inhibitors. Cell. Mol. Life Sci. 2012, 69, 2409-2427. [CrossRef]

91. Dias, V.; Junn, E.; Mouradian, M.M. The role of oxidative stress in Parkinson's disease. J. Park. Dis. 2013, 3, 461-491. [CrossRef]

92. Puspita, L.; Chung, S.Y.; Shim, J.-W. Oxidative stress and cellular pathologies in Parkinson's disease. Mol. Brain 2017, 10, 53. [CrossRef]

93. Jenner, P. Oxidative stress in Parkinson's disease. Ann. Neurol. 2003, 53 (Suppl. 3), S26-S36. [CrossRef] [PubMed]

94. Rahimmi, A.; Khosrobakhsh, F.; Izadpanah, E.; Moloudi, M.R.; Hassanzadeh, K. N-acetylcysteine prevents rotenone-induced Parkinson's disease in rat: An investigation into the interaction of parkin and Drp1 proteins. Brain Res. Bull. 2015, 113, 34-40. [CrossRef] [PubMed]

95. Olanow, C.W.; Schapira, A.H.V.; LeWitt, P.A.; Kieburtz, K.; Sauer, D.; Olivieri, G.; Pohlmann, H.; Hubble, J. TCH346 as a neuroprotective drug in Parkinson's disease: A double-blind, randomised, controlled trial. Lancet Neurol. 2006, 5, 1013-1020. [CrossRef]

96. Lim, K.-L.; Tan, J.M.M. Role of the ubiquitin proteasome system in Parkinson's disease. BMC Biochem. 2007, 8 (Suppl. 1), S13. [CrossRef]

97. Hassanzadeh, K.; Rahimmi, A. Oxidative stress and neuroinflammation in the story of Parkinson's disease: Could targeting these pathways write a good ending? J. Cell. Physiol. 2018, 234, 23-32. [CrossRef] [PubMed]

98. Edgar, R.S.; Green, E.W.; Zhao, Y.; van Ooijen, G.; Olmedo, M.; Qin, X.; Xu, Y.; Pan, M.; Valekunja, U.K.; Feeney, K.A.; et al. Peroxiredoxins are conserved markers of circadian rhythms. Nature 2012, 485, 459-464. [CrossRef] [PubMed]

99. O’Neill, J.S.; Reddy, A.B. Circadian clocks in human red blood cells. Nature 2011, 469, 498-503. [CrossRef] [PubMed]

100. Lee, J.; Kim, M.-S.; Li, R.; Liu, V.Y.; Fu, L.; Moore, D.D.; Ma, K.; Yechoor, V.K. Loss of Bmal1 leads to uncoupling and impaired glucose-stimulated insulin secretion in $\beta$-cells. Islets 2011, 3, 381-388. [CrossRef] [PubMed]

101. Wanagat, J.; Dai, D.-F.; Rabinovitch, P. Mitochondrial oxidative stress and mammalian healthspan. Mech. Ageing Dev. 2010, 131, 527-535. [CrossRef] 
102. Beaver, L.M.; Klichko, V.I.; Chow, E.S.; Kotwica-Rolinska, J.; Williamson, M.; Orr, W.C.; Radyuk, S.N.; Giebultowicz, J.M. Circadian regulation of glutathione levels and biosynthesis in Drosophila melanogaster. PLoS ONE 2012, 7, e50454. [CrossRef] [PubMed]

103. Krishnan, N.; Davis, A.J.; Giebultowicz, J.M. Circadian regulation of response to oxidative stress in Drosophila melanogaster. Biochem. Biophys. Res. Commun. 2008, 374, 299-303. [CrossRef] [PubMed]

104. Krishnan, N.; Kretzschmar, D.; Rakshit, K.; Chow, E.; Giebultowicz, J.M. The circadian clock gene period extends healthspan in aging Drosophila melanogaster. Aging 2009, 1, 937-948. [CrossRef] [PubMed]

105. Musiek, E.S. Circadian clock disruption in neurodegenerative diseases: Cause and effect? Front. Pharmacol. 2015, 6, 29. [CrossRef]

106. Musiek, E.S.; Lim, M.M.; Yang, G.; Bauer, A.Q.; Qi, L.; Lee, Y.; Roh, J.H.; Ortiz-Gonzalez, X.; Dearborn, J.T.; Culver, J.P.; et al. Circadian clock proteins regulate neuronal redox homeostasis and neurodegeneration. J. Clin. Investig. 2013, 123, 5389-5400. [CrossRef]

107. Anglade, P.; Vyas, S.; Javoy-Agid, F.; Herrero, M.T.; Michel, P.P.; Marquez, J.; Mouatt-Prigent, A.; Ruberg, M.; Hirsch, E.C.; Agid, Y. Apoptosis and autophagy in nigral neurons of patients with Parkinson's disease. Histol. Histopathol. 1997, 12, 25-31.

108. Gupta, A.; Dawson, V.L.; Dawson, T.M. What causes cell death in Parkinson's disease? Ann. Neurol. 2008, 64 (Suppl. 2), S3-S15. [CrossRef]

109. Glass, C.K.; Saijo, K.; Winner, B.; Marchetto, M.C.; Gage, F.H. Mechanisms underlying inflammation in neurodegeneration. Cell 2010, 140, 918-934. [CrossRef]

110. Ramesh, G.; MacLean, A.G.; Philipp, M.T. Cytokines and chemokines at the crossroads of neuroinflammation, neurodegeneration, and neuropathic pain. Mediators Inflamm. 2013, 2013, 480739. [CrossRef]

111. Tufekci, K.U.; Meuwissen, R.; Genc, S.; Genc, K. Inflammation in Parkinson's disease. Adv. Protein Chem. Struct. Biol. 2012, 88, 69-132. [PubMed]

112. Rocha, N.P.; de Miranda, A.S.; Teixeira, A.L. Insights into Neuroinflammation in Parkinson's Disease: From Biomarkers to Anti-Inflammatory Based Therapies. BioMed Res. Int. 2015, 2015, 628192. [CrossRef]

113. Shih, R.-H.; Wang, C.-Y.; Yang, C.-M. NF-kappaB Signaling Pathways in Neurological Inflammation: A Mini Review. Front. Mol. Neurosci. 2015, 8, 77. [CrossRef] [PubMed]

114. Yacoubian, T.A.; Standaert, D.G. Targets for neuroprotection in Parkinson's disease. Biochim. Biophys. Acta 2009, 1792, 676-687. [CrossRef] [PubMed]

115. Moussaud, S.; Jones, D.R.; Moussaud-Lamodière, E.L.; Delenclos, M.; Ross, O.A.; McLean, P.J. Alpha-synuclein and tau: Teammates in neurodegeneration? Mol. Neurodegener. 2014, 9, 43. [CrossRef] [PubMed]

116. Guerreiro, P.S.; Gerhardt, E.; Lopes da Fonseca, T.; Bähr, M.; Outeiro, T.F.; Eckermann, K. LRRK2 Promotes Tau Accumulation, Aggregation and Release. Mol. Neurobiol. 2016, 53, 3124-3135. [CrossRef] [PubMed]

117. Russo, I.; Bubacco, L.; Greggio, E. LRRK2 and neuroinflammation: Partners in crime in Parkinson's disease? J. Neuroinflammation 2014, 11, 52. [CrossRef]

118. Curtis, A.M.; Fagundes, C.T.; Yang, G.; Palsson-McDermott, E.M.; Wochal, P.; McGettrick, A.F.; Foley, N.H.; Early, J.O.; Chen, L.; Zhang, H.; et al. Circadian control of innate immunity in macrophages by miR-155 targeting Bmal1. Proc. Natl. Acad. Sci. USA 2015, 112, 7231-7236. [CrossRef]

119. Bellet, M.M.; Deriu, E.; Liu, J.Z.; Grimaldi, B.; Blaschitz, C.; Zeller, M.; Edwards, R.A.; Sahar, S.; Dandekar, S.; Baldi, P.; et al. Circadian clock regulates the host response to Salmonella. Proc. Natl. Acad. Sci. USA 2013, 110, 9897-9902. [CrossRef]

120. Arjona, A.; Sarkar, D.K. The circadian gene mPer2 regulates the daily rhythm of IFN-gamma. J. Interferon Cytokine Res. Off. J. Int. Soc. Interferon Cytokine Res. 2006, 26, 645-649. [CrossRef]

121. Silver, A.C.; Arjona, A.; Walker, W.E.; Fikrig, E. The circadian clock controls toll-like receptor 9-mediated innate and adaptive immunity. Immunity 2012, 36, 251-261. [CrossRef] [PubMed]

122. Keller, M.; Mazuch, J.; Abraham, U.; Eom, G.D.; Herzog, E.D.; Volk, H.-D.; Kramer, A.; Maier, B. A circadian clock in macrophages controls inflammatory immune responses. Proc. Natl. Acad. Sci. USA 2009, 106, 21407-21412. [CrossRef] [PubMed]

123. Preitner, N.; Damiola, F.; Lopez-Molina, L.; Zakany, J.; Duboule, D.; Albrecht, U.; Schibler, U. The orphan nuclear receptor REV-ERBalpha controls circadian transcription within the positive limb of the mammalian circadian oscillator. Cell 2002, 110, 251-260. [CrossRef] 
124. Narasimamurthy, R.; Hatori, M.; Nayak, S.K.; Liu, F.; Panda, S.; Verma, I.M. Circadian clock protein cryptochrome regulates the expression of proinflammatory cytokines. Proc. Natl. Acad. Sci. USA 2012, 109, 12662-12667. [CrossRef] [PubMed]

125. Csernus, V.; Mess, B. Biorhythms and pineal gland. Neuro Endocrinol. Lett. 2003, 24, 404-411. [PubMed]

126. Dubocovich, M.L. Melatonin receptors: Role on sleep and circadian rhythm regulation. Sleep Med. 2007, 8 (Suppl. 3), 34-42. [CrossRef]

127. Pevet, P.; Challet, E. Melatonin: Both master clock output and internal time-giver in the circadian clocks network. J. Physiol. Paris 2011, 105, 170-182. [CrossRef]

128. Mauriz, J.L.; Collado, P.S.; Veneroso, C.; Reiter, R.J.; González-Gallego, J. A review of the molecular aspects of melatonin's anti-inflammatory actions: Recent insights and new perspectives. J. Pineal Res. 2013, 54, 1-14. [CrossRef]

129. Crowley, S.J.; Eastman, C.I. Melatonin in the afternoons of a gradually advancing sleep schedule enhances the circadian rhythm phase advance. Psychopharmacology (Berl.) 2013, 225, 825-837. [CrossRef]

130. Wu, Y.-H.; Swaab, D.F. The human pineal gland and melatonin in aging and Alzheimer's disease. J. Pineal Res. 2005, 38, 145-152. [CrossRef]

131. Cardinali, D.P.; Pagano, E.S.; Scacchi Bernasconi, P.A.; Reynoso, R.; Scacchi, P. Melatonin and mitochondrial dysfunction in the central nervous system. Horm. Behav. 2013, 63, 322-330. [CrossRef] [PubMed]

132. Wang, X.; Sirianni, A.; Pei, Z.; Cormier, K.; Smith, K.; Jiang, J.; Zhou, S.; Wang, H.; Zhao, R.; Yano, H.; et al. The melatonin MT1 receptor axis modulates mutant Huntingtin-mediated toxicity. J. Neurosci. Off. J. Soc. Neurosci. 2011, 31, 14496-14507. [CrossRef] [PubMed]

133. Rosales-Corral, S.A.; Acuña-Castroviejo, D.; Coto-Montes, A.; Boga, J.A.; Manchester, L.C.; Fuentes-Broto, L.; Korkmaz, A.; Ma, S.; Tan, D.-X.; Reiter, R.J. Alzheimer's disease: Pathological mechanisms and the beneficial role of melatonin. J. Pineal Res. 2012, 52, 167-202. [CrossRef] [PubMed]

134. Galano, A.; Tan, D.X.; Reiter, R.J. On the free radical scavenging activities of melatonin's metabolites, AFMK and AMK. J. Pineal Res. 2013, 54, 245-257. [CrossRef] [PubMed]

135. Calvo, J.R.; González-Yanes, C.; Maldonado, M.D. The role of melatonin in the cells of the innate immunity: A review. J. Pineal Res. 2013, 55, 103-120. [CrossRef] [PubMed]

136. Zhang, H.-M.; Zhang, Y. Melatonin: A well-documented antioxidant with conditional pro-oxidant actions. J. Pineal Res. 2014, 57, 131-146. [CrossRef]

137. Guven, C.; Taskin, E.; Akcakaya, H. Melatonin Prevents Mitochondrial Damage Induced by Doxorubicin in Mouse Fibroblasts Through Ampk-Ppar Gamma-Dependent Mechanisms. Med. Sci. Monit. Int. Med. J. Exp. Clin. Res. 2016, 22, 438-446. [CrossRef]

138. Kato, H.; Tanaka, G.; Masuda, S.; Ogasawara, J.; Sakurai, T.; Kizaki, T.; Ohno, H.; Izawa, T. Melatonin promotes adipogenesis and mitochondrial biogenesis in 3T3-L1 preadipocytes. J. Pineal Res. 2015, 59, 267-275. [CrossRef]

139. Singhal, N.K.; Srivastava, G.; Patel, D.K.; Jain, S.K.; Singh, M.P. Melatonin or silymarin reduces maneb- and paraquat-induced Parkinson's disease phenotype in the mouse. J. Pineal Res. 2011, 50, 97-109. [CrossRef]

140. Chuang, J.-I.; Pan, I.-L.; Hsieh, C.-Y.; Huang, C.-Y.; Chen, P.-C.; Shin, J.W. Melatonin prevents the dynamin-related protein 1-dependent mitochondrial fission and oxidative insult in the cortical neurons after 1-methyl-4-phenylpyridinium treatment. J. Pineal Res. 2016, 61, 230-240. [CrossRef]

141. Ortiz, G.G.; Pacheco-Moisés, F.P.; Gómez-Rodríguez, V.M.; González-Renovato, E.D.; Torres-Sánchez, E.D.; Ramírez-Anguiano, A.C. Fish oil, melatonin and vitamin E attenuates midbrain cyclooxygenase-2 activity and oxidative stress after the administration of 1-methyl-4-phenyl-1,2,3,6- tetrahydropyridine. Metab. Brain Dis. 2013, 28, 705-709. [CrossRef] [PubMed]

142. López, A.; Ortiz, F.; Doerrier, C.; Venegas, C.; Fernández-Ortiz, M.; Aranda, P.; Díaz-Casado, M.E.; Fernández-Gil, B.; Barriocanal-Casado, E.; Escames, G.; et al. Mitochondrial impairment and melatonin protection in parkinsonian mice do not depend of inducible or neuronal nitric oxide synthases. PLoS ONE 2017, 12, e0183090. [CrossRef] [PubMed]

143. Choi, S.-H.; Aid, S.; Bosetti, F. The distinct roles of cyclooxygenase-1 and -2 in neuroinflammation: Implications for translational research. Trends Pharmacol. Sci. 2009, 30, 174-181. [CrossRef] [PubMed] 